\title{
Effect of Type of Hay and Concentrate Level in Intake and Digestibility in Diets for Goats
}

\section{R. O. Arias ${ }^{1}$, M.G. Muro1, M.S. Trigo1, S. Deschamps, J. Origlia², D. Gornatti Churria2 ${ }^{2}$ A. A CATTANEO ${ }^{3}$, C.A. Cordiviola1 ${ }^{1}$}

\author{
${ }^{1}$ Faculty of Agricultural and Forestry Sciences. UNLP. Course Introduction to Animal Production \\ ${ }^{2}$ Faculty of Veterinary Cience. Course Pathology of birds and pilipers \\ ${ }^{3}$ IGEVET, Faculty of Veterinary \\ ( 60 y 119 s/n La Plata. Buenos Aires. Argentina )
}

\begin{abstract}
Summary: The aim of this study was to evaluate the effect of the level of hay and concentrate on total hay intake and supplied already, the additive/substitutive effect and total apparent digestibility of the diet intake in diets for goats. Experiment I: diets: Alfalfa hay (A1), Alfalfa hay + corn (0.5\% LW/day) (A2), + 1\% LW/day (A3), + 1.5\% LW/day (A4). Experiment II: diets: Natural grassland hay $(\mathrm{CN})(\mathrm{R} 1)$, hay $\mathrm{CN}+$ corn $(0.5 \% \mathrm{LW} /$ day) (R2), hay CN + corn (1\% of LW/day) (R3), $+1.5 \%$ of LW/day) (R4). Intake, ratio forage/concentrate and total apparent digestibility were calculated. Experiment I: There were no effects $(p>0.05)$ on the CMST for the corn tested levels and recorded a linear decrease $(\mathrm{p}<0.05)$ in the CTFDN, CTFDA and CTPB. The CMSF decreased linearly $(\mathrm{p}<0.05)$ with increasing amounts of corn by verifying a hay effect on the concentrate. The F/C was different $(\mathrm{p}<0.05)$ in all treatments. The DTAIVMS increases linearly $(\mathrm{p}<0.05)$ with the content of corn in the diet. Experiment II: a linear increase $(\mathrm{p}<0.05)$ on the CMST and CTPB with increasing corn in diet and no differences $(\mathrm{p}>0.05)$ on the CMSF, CTFDN and CTFDA is observed. The F/C and CTPB differ $(\mathrm{p}<0.05)$ among all the diets tested. The DTAIVMS increases linearly $(\mathrm{p}<0.05)$ with the content of corn in the diet. Therefore, it can be concluded that the increase of maize levels improved the total digestibility of the ration consumed and the substitute or additive effect depended on the quality of the hay used.
\end{abstract}

Keywords: goats, concentrated, fiber

\section{Introduction}

Extensive production of goats is based on the utilization of forage. Alfalfa is considered valuable forage to feed goats for their high protein content and a lower concentration of neutral detergent fiber. The high content of soluble fiber high degradability and low NDF has a positive effect on rumen fill and dry matter intake (Rapetti et al., 2005). However, there is a trend towards intensification and increased use of concentrates to sustain high levels of productivity (Russell \& Rychlik 2001; Castel et al., 2003).

Goats change their feeding behavior according to the availability of forage or concentrate, and its ability to select foods high protein content and digestibility, adapting to different conditions, ranging from grassland to the desert (Provence et al., 2003; Rapetti \& Bava, 2008).
The change in digestibility, by an effect of increased voluntary consumption, is recognized for the first time in the models of animal nutrition, from publications table requirements for dairy cattle NRC (NRC, 2001). In ruminant feed digestibility plays an important role in regulating consumption when digestibility is less than $68 \%$ the filling effect occurs and regulation is of mechanical type and occurs when the animal can't consume more due to a limitation physical gastrointestinal tract. Variations in digestibility caused mainly are the lignin concentration in forage. Lignin has no nutritional value and also blocks access of microorganisms to structural carbohydrates such as cellulose and hemicellulose (Relling \& Mattioli, 2013). The digestibility is an intrinsic property of the forage, while the voluntary consumption is a function of the forage, the animal and the environment under which they feed. Combining both, apparent digestibility of dry matter in vivo and intake of dry matter, resulting in the intake of digestible dry matter (Coleman et al.,

This article is published under the terms of the Creative Commons Attribution License 4.0 Author(s) retain the copyright of this article. Publication rights with Alkhaer Publications. Published at: http://www.ijsciences.com/pub/issue/2017-02/

DOI: 10.18483/ijSci.1191; Online ISSN: 2305-3925; Print ISSN: 2410-4477 
1999). INRA in 1979 and improved in 1987 incorporates the concept of Ballast Unit (UL) food, to represent the ingestibilidad forage. Mertens (1987) postulates a negative effect of NDF pasture intake and maximum intake values FDN should not exceed $1.2 \%$ of live animal weight or $35 \%$ of that fraction in the diet. Mertens (2010), the equation of Van Soest (Goering and Van Soest, 1970) describes the mathematical relationship of the DM digestibility (DDM), digestibility of neutral detergent fiber (NDFD) and digestibility of its complement, soluble in neutral detergent. The equation mentioned is: $\mathrm{DDM}=87.1-(0.98-\mathrm{DFDN}) \mathrm{x}$ FDN. This equation indicates a negative relation between DM digestibility and NDF. It also suggests that if the NDF concentration and its digestibility are known, it is better described the variation that most affects the DDM, which variable is related to the energy of the feed available to the animal.

Another limiting factor to intake is the proportion protein in the diet, with values less than $8 \%$ decrease intake animals (Aello \& Di Marco, 2000)

When ruminants consume forage and receive supplements, consumption of dry matter forage generally decreases, which is known as replacement rate (Viglizzo, 1981; Minson, 1982; Kellaway \& Porta, 1993; Stock dale, 2000). If pastored quality forage is insufficient, proper supplementation can increase the amounts ingested forage and therefore the total consumption of MS, this phenomenon is known as an addition (NRC, 1987; Minson, 1990; Mayne, 2007).

The incorporation of corn grain in ruminant feed increases the digestibility of dry matter consumed however could reduce forage digestibility (Archimède et al., 1995; Molina \& Alcaide et al., 2000; Fimbres et al., 2002; Rapetti et al., 2004). Foods like mature hays and pastures induce $\mathrm{pH}$ values of 6.5 to 6.8 , optimal for cellulolysis predominance of acetic acid with (Aello \& Di Marco, 2000). High starch content reduces the fiber digestion due to microbial fermentation of nonstructural carbohydrates, reduced ruminal $\mathrm{pH}$ and cellulolytic lower activity (Mould \& Orskov 1984; Kovacik et al., 1986; Grant \& Mertens, 1992; GarcesYepez et al., 1997; Arias et al., 2013; Arias et al., 2015).

The aim of this study was to evaluate the effect of the level of hay and concentrate on total hay intake and supplied already, the additive / substitutive effect and total apparent digestibility of the diet intake in diets for goats.

\section{Materials and methods}

This production was regulated and authorized by the Institutional Committee for the Care and Use of Laboratory Animals of the Faculty of Veterinary Sciences of the National University of La Plata. Whose file number is 0600-008961 / 12-000

The study was conducted in goat's experimental unit of the Faculty of Agricultural and Forestry Sciences of the National University of La Plata.

4 goats' crosses (Nubian x Creole) and 5 years old and $39.77 \pm 1.07 \mathrm{~kg}$ live weight (LW) were used on average. The experimental design was a $4 \times 4$ Latin square with a repeat, with 7-day wash-out between periods. During the time in which the determinations were made, the goats were housed in individual compartments $(0.80 \mathrm{~m} \times 1.50 \mathrm{~m})$ with wooden slatted floor (slats), feeders and automatic waters type pacifier with free access to water. The weight of each animal at the beginning of each period is recorded.

\section{Experiments and tested diets.}

Experiment I: 4 diets were provided:

- $\quad$ Alfalfa hay (A1)

- Alfalfa hay + ground grain corn $(0.5 \%$ LW / day) (A2)

- $\quad$ Alfalfa hay + ground grain corn (1\% LW / day) (A3)

- $\quad$ Alfalfa hay + ground grain corn $(1.5 \% \mathrm{LW} /$

day) (A4)

Experiment II: 4 diets were provided:

- $\quad$ Natural grassland hay $(\mathrm{CN})(\mathrm{R} 1)$

- Hay $\mathrm{CN}+$ ground grain corn $(0.5 \% \mathrm{LW} /$ day) (R2)

- $\quad$ Hay $\mathrm{CN}+$ ground grain corn ( $1 \%$ of LW / day) (R3)

- $\quad$ Hay $\mathrm{CN}+$ ground grain corn $(1.5 \%$ of LW / day) (R4)

The predominant species were hay $\mathrm{CN}$, Briza subaristata, Stipa neesiana, Paspalum dilatatum, Bothriochloa legaloides; Lolium multiflorum.

A period of fifteen days to get used to each diet was implemented prior to sampling. The quantities of corn were delivered increasingly, starting with $70 \mathrm{~g}$ per animal per day, reaching the proportions of each treatment at the beginning of the second week adjustment period. Diets were supplied in a single delivery at 9 am each day. Dry material of hay and corn by drying in an oven (SOMCIC) at $90-95^{\circ} \mathrm{C}$ for 24 hours was determined (AOAC, 1995). Alfalfa hay and $\mathrm{CN}$ was provided ad libitum and the chemical composition of foods used are noted in Table 1. 


\section{Determining intake, ratio forage / concentrate and total apparent digestibility}

In experiments I and II determining the fodder consumption was performed during the 4 days of feces collection, after the habituation period to the different diets. To ensure ad libitum character of supply feeders they remained consistently provided the recorded amounts of spiked hay, using an electronic scale model Croma brand Systel. Intake of total dry matter (CMST) was calculated by summing the dry matter provided by the hay (CMSF) and corn (CMSMz) expressed in $\mathrm{Kg} /$ day. The concentrated feed ratio $(\mathrm{F} / \mathrm{C})$ was rated as the proportion of hay and concentrate consumed with respect to CMST.

It was collected and the excreted fecal matter is quantified by collecting bag. These were hollowed out once a day daily weighing all dregs and a subsample consisting of $10 \%$ of the evacuated was determined dry matter (AOAC, 1995). Total digestibility of dry matter consumed from the difference between the ingested and excreted in relation to ingested, expressed as percentages (\%) was calculated.

\section{Statistical Analyses}

Statistical model:

$\mathrm{Y}=\mu+\mathrm{T}+\mathrm{UE}+\mathrm{P}+\mathrm{e}$

$\mathrm{Y}$ : dependent variable

$\mu$ : average overall trial

$\mathrm{T}$ : treatment

EU: experimental unit

P: period

e: error

Data were analyzed by MIXED procedure (SAS, 2004) for a $4 \times 4$ Latin squares, using a mixed model that included the fixed effect of sampling (treatment period) and the random effect of the animal. Orthogonal polynomial contrasts were used to determine linear effects (L), quadratic (Q) and cubic (C) of increasing levels of ground corn in the variables analyzed. The differences were considered significant with a $\mathrm{P}$ value of $<0.05$ and trends $0.05<\mathrm{P}$ $<0.10$. In experiment II a simple linear regression was performed to determine correlation between the total dry matter intake and intake of PB and total dry matter digestibility.

\section{Results and discussion}

Experiment I: Through analysis of orthogonal polynomial contrasts, no significant effects $(\mathrm{p}>0.05)$ were observed in the CMST to concentrate levels tested and recorded a significant linear decrease ( $p$
$<0.05)$ in the CTFDN, CTFDA and CTPB. CMSF decreases linearly $(p<0.05)$ with increasing amounts of ground corn verifying a substitute effect concentrated on alfalfa hay (Figure 1). CMSF, CTFDN, CTFDA and CTPB the $\mathrm{A}_{4}$ diet was significantly lower $(p<0.05)$ than the $A_{1}$ and $A_{2}$ diet. The F/C differed significantly $(p<0.05)$ among all treatments. The DTAIVMS increases linearly ( $p$ $<0.05)$ with the content of corn in the diet. By analyzing average DTAIVMS verified that the $\mathrm{A}_{4}$ was significantly higher $(p<0.05)$ than $A_{1}$ and $A_{2}$ (Table 2).

Experiment II: a significant linear increase ( $p<0.05)$ on the CMST and CTPB with increasing corn in diet and no significant differences ( $p>0.05$ ) on the CMSF, CTFDN and CTFDA is observed. The F/C and CTPB differ significantly $(p<0.05)$ among all the diets tested. The DTAIVMS increases linearly ( $p$ $<0.05)$ with the content of corn in the diet. The digestibility of diet with a higher proportion of corn was significantly higher $(\mathrm{p}<0.05)$ than the other treatments (Table 3 ). Figure 2 verifies the additive effect of the increase concentrated in assigned diets.

The simple regression analysis fitted a linear model (Figure 3) to describe the relation between total dry matter intake and total PB intake. Adjusted model:

$$
\mathrm{CMST}=170.46+13.036^{*} \mathrm{CTPB}
$$

The P-value in the ANOVA table (Table 4) is less than 0.05 there is a statistically significant relationship between CMST and CTPB. The Rsquare indicates that the adjusted model accounted for $88.9829 \%$ of the variability in CMST. The correlation coefficient is equal to 0.943308 , indicating a relatively strong relation between the variables.

Following the same analysis to relate total dry matter intake and total dry matter digestibility, the results adjusted to a linear model (Figure 4). Adjusted model:

\section{$\mathrm{CMST}=449.286+9.2497 *$ DTAIVMS}

The P-value in the ANOVA table (Table 5) is less than 0.05 there is a statistically significant relationship between CMST and DTAIVMS. The Rsquare indicates that the adjusted model accounted for $88.9829 \%$ of the variability in CMST. The correlation coefficient is equal to 0.5969 , indicating a moderately strong relation between variables.

When the animals were given supplements consumption decreased forage dry matter (Viglizzo, 1981; Minson, 1982; Kellaway \& Porta, 1993; Stock 
dale, 2000), which is known as replacement rate. In Experiment I, the substitution effect is observed, verifying the change in feeding behavior cited by Provenza et al., (2003); Rapetti \& Bava, (2008) in relation to consumption of forage or concentrated and capacity to select food goats high digestibility and adaptation to different types of diets. In experiment 2 in accordance with NRC, 1987; Minson, 1990; Mayne, 2007 the additive effect was proved due to incorporation of corn to the diet with hay $\mathrm{CN}$ which increased digestibility and total dry matter intake (Molina \& Alcaide et al., 2000; Fimbres et al., 2002; Rapetti et al., 2004; Archimède et al., 1995).

It coincides with Coleman et al., (1999); NRC (2001) that the apparent digestibility of the dry matter in vivo and the intake of dry matter results in the consumption of dry matter digestible. In this paper according to Mertens (2010) and Relling \& Mattioli (2013) it was shown an inverse relation between the fiber content of the diet and total intake. In accordance with Aello 2000, in experiment II was verified that the increase in $\mathrm{PB}$ diet increased the total dry matter intake.

The incorporation corn grain to the diet improved the apparent total digestibility. Although ruminal $\mathrm{pH}$ was not measured, it was probable that the quantities of grain tested decreased the digestibility of the fiber (Mould \& Orskov 1984; Kovacik et al., 1986; Grant \& Mertens, 1992; Garces-Yepez et al., 1997; Arias et al., 2013; Arias et al., 2015).

\section{Conclusion}

Therefore, it can be concluded that the increase of corn levels improved the total digestibility of the ration consumed and the substitute or additive effect depended on the quality of the hay used.

\section{References}

1) Aello M., O. Di Marco. 2000. Consumo. In Nutrición animal. (ed) Universidad Nacional de Mar del Plata. Facultad de Ciencias Agrarias. Balcarce, Argentina. pp: 163-185.

2) AOAC. 1995. Dry mater in Animal Feed. Method number 934.01. In: Official Methods of Analysis of AOAC International. 16 th ed. vol. I. Association of Official Analytical Chemists, Arlington, VA, USA, pp, I (Chapter 4).

3) Archimède, H., D. Sauvant, J. Hervieu, C. Poncet \& M. Dorleans. 1995. Digestive interactions in the ruminant relationships between whole tract and stomach evaluation. Anim. Feed Sci. Technol. 54:327-340.

4) Arias, R., M. G. Muro, C.A. Cordiviola, M.S Trigo, M. Brusa, R. A. Lacchini. 2013. Incidencia de la proporción de maíz sobre la degradabilidad in situ de heno de alfalfa en dietas para caprinos. Revista de la Facultad de Agronomía, La Plata. Vol 112 (2): 62-67.

5) Arias, R., M. G. Muro, C.A. Cordiviola, A. C. Cattáneo, M.S Trigo \& R.A. Lacchini. 2015. Efecto de la suplementación con grano de maíz sobre la digestibilidad in vivo de heno de alfalfa en caprinos. Revista de la Facultad de Agronomía, La Plata. Vol 114 (1): 44-48.
6) Bach A, S Calsamiglia, MD Andstern. 2005. Nitrogen metabolism in the rumen. Journal of Dairy Science. 88, E9E21.

7) Castel, J.M; Y. Delgado-Pertíñez, J. Camúñez, J. Basulto, F. Caravaca, J.L. Guzmán, M.J. Alcalde. 2003. Characterisation of semi extensive goat production systems in Southern Spain. Small Ruminall Res 47, 1-11.

8) Cerrillo, M. A., J. R. Russell \& M. H. Crump. 1999. The effects of hay maturity and forage to concentrate ratio on digestion kinetics in goats. Small Rumin. Res. 32, 51-60.

9) Coleman, S.W., Lippke, H. \& Gill, M. 1999. Estimating the nutritive potential of forages. In: Nutritional Ecology of Herbivores (Ed.H.J. Jung y G.C. Fahey), pp. 647.

10) Fimbres, H., J. R. Kawas, G. Hernandez-Vidal, J. F. PiconRubio, C. D. Lu. 2002. Nutrient intake, digestibility, mastication and ruminal fermentation of lambs fed finishing ration with various forage levels. Small Rumin. Res. 43, 275281.

11) Goering, H.K. and Van Soest, P.J. 1970. Forage fiber analysis (apparatus, reagents, procedures and some applications). Agricultural Handbook $\mathrm{N}^{\circ} 379$ ARS-USDA, Washington, DC

12) INRA. 1987. Laboratoire de recherche sur la viande. Centre de recherche de Jouy-en-Josas, Jouy-en-Josas, Versailles, France. Vol 5, $251 \mathrm{pp}$.

13) Kellaway, R. \& S. Porta. 1993. Feeding concentrates supplements for dairy cows. Dairy Research and Development Corporation. Australia. 176 pp.

14) Komarek, A. R., J. B. Robertson \& P. J. Van Soest. 1994 Comparison of the filter bag technique to conventional filtration in the Van Soest Analysis of 21 feeds. In: Proc. Natl. Conf. on Forage Quality, Evaluation and Utilization, Lincoln, NE. pp.78.

15) Lu, C. D.; J. R. Kawas; O. G. Mahgoub. 2005. Fibre digestión and utilization in goats. Small Rumin. Res. 60, 4552.

16) Mayne, J. 2007. Challenges and Lessons in Implementing Results-Based Management. Evaluation, 13, 89-107.

17) Matejovsky, K.M.D \& W. Sanson. 1995. Intake and digestion of low-, medium-, and high- quality grass hays by lambs receiving increasing levels of corn supplementation. J. Anim. Science.73, 2156-2163.

18) Mertens, D.R. 1987. Predicting intake and digestibility using mathematical models of ruminal function. J. of Animal Sci. 64, 1548-1558.

19) Mertens, D.R. 2010. NDF and DMI - has anything changed? $<$ http//www.ansci.cornell.educnconf2010proceedingsCNC20 10.18. Mertens.pdf> [Consulta: 24 enero de 2017].

20) Minson, D. J. 1982. Effects of chemical and physical composition of herbage eaten upon intake. In Nutritional Limits to Animal Production from Pastures, pp. 167-182 [J. B. Hacker, editor]. Farnham Royal: Commonwealth Agricultural Bureaux.

21) Minson, D.J. 1990. Forage in ruminant nutrition. Academic Press, San Diego, 483 pp.

22) Molina-Alcaide, E., A.I. Martín-García, J.F. Aguilera. 2000 A comparative study of nutrient digestibility, kinetics of degradation and passage and rumen fermentation pattern in goats and sheep offered good quality diets. Livest. Prod. Science.64, 215-223.

23) Mould, F. L \& E.R. Orskov. 1984. Manipulation of rumen fenid $\mathrm{pH}$ and influence on cellulose in sacco, dry matter degradation and the run microflora of sheep offered either hay or concentrate. Animal Feed Science and Technology. 10, $1-14$.

24) NRC. 1987. "Predicting feed intake of food-producing animals". National Academy Press. Washington, D.C.

25) NRC. 2001. National Research Council. Nutrient Requirements of Dairy Cattle.7th rev. ed. Natl. Acad. Press Washington, DC. USA

26) Provenza, F.D., J.J. Villalba, L.E. Dziba, S.B. Atwood, R.E Banner. 2003. Linking herbivore experience, varied diets, 
and plant biochemical diversity. Small Ruminant Research. 49, 257-274

27) Rapetti, L., L. Bava, A. Tamburini, G.M. Crovetto. 2005. Feeding behaviour, digestibility, energy balance and productive performance of lactating goats fed forage-based and forage-free diets. Italian Journal of Animal Science. 4, 71-83.

28) Rapetti, L \& L. Bava. 2008. Feeding Management of Dairy Goats in Intensive Systems. In: Dary goats Feedeing and Nutrition. (ed). Cannas A, G Pulina (ed). Milan, Italy, p. 221337.

29) Relling A \& Mattioli G. 2013. Fisiología digestiva y metabólica de los rumiantes. Ed: Facultad de Ciencias Veterinarias. UNLP. 104 pp.

30) Russell, J. B \& J. L. Rychlik. 2001. Factors that alter rumen microbial ecology. Science 292, 1119-1122.
31) SAS Institute Inc. 2004 SAS On lineDoc* 9.1.3. Cary, NC: SAS Institute. Inc.

32) Van Soest, P.J, Robertson, J.B., Lewis, B.A. 1991. Methods for dietary fiber neutral detergent fiber and non-starch polysaccharids in relation to animal nutrition. J.Dairy Sc.74, 3583-3597.

33) Viglizzo, E. 1981. Dinámica de los sistemas pastoriles de producción de leche. Cap. 8: La suplementación de pasturas. Ed. Hemisferio Sur. p. 67-82.

34) Yanez-Ruiz, D. R., A. Moumen, A. I. Martin-Garcia, and E. Molina-Alcaide. 2004. Ruminal fermentation and degradation patterns, protozoa population, and urinary purine derivatives excretion in goats and wethers fed diets based on two-stage olive cake: Effect of PEG supply. J. Anim. Sci. 82, 2023-2032.

Table 1: Chemical composition of food (*)

\begin{tabular}{lccc}
\hline Ítem & Hay de Alfalfa & Hay de CN & Corn \\
\hline MS\% & 87 & 88 & 89 \\
PB\% & 13,7 & 5,8 & 7,3 \\
FDN\% & 58,7 & 74 & 14,55 \\
FDA\% & 46,03 & 44 & 3,68 \\
Hemicellulose \% & 12,84 & 30 & 0,87 \\
Cellulose \% & 35,36 & 26,32 & 2,13 \\
Lignin \% & 10,67 & 17,68 & 1,55 \\
\hline
\end{tabular}

* Laboratory of biochemistry of the Faculty of Agrarian and Forest Sciences. UNLP.

MS: dry matter.

PB: crude protein.

FDN: Neutral Detergent Fiber.

FDA: Acid Detergent Fiber. 
Table 2: CMST, CMSF, CTFDN, CTFDA, CTPB, DTAIVMS, F / C of the experiment I

\begin{tabular}{|c|c|c|c|c|c|c|c|c|c|}
\hline \multirow{2}{*}{ Ítem } & \multicolumn{4}{|c|}{ Diet } & \multirow{2}{*}{$\mathbf{E E}$} & \multicolumn{3}{|c|}{ Contrast } & \multirow[t]{2}{*}{ P-value } \\
\hline & $\mathbf{A}_{1}$ & $\mathbf{A}_{2}$ & $\mathbf{A}_{3}$ & $\mathbf{A}_{4}$ & & $\mathbf{L}$ & $\mathbf{Q}$ & $\mathrm{C}$ & \\
\hline CMST (Kg/día) & $1,130^{\mathrm{a}}$ & $1,210^{\mathrm{a}}$ & $1,256^{\mathrm{a}}$ & $1,200^{\mathrm{a}}$ & 0,236 & 0,610 & 0,466 & 0,891 & 0,794 \\
\hline CMSF (Kg/día) & $1,130^{\mathrm{a}}$ & $0,926^{\mathrm{a}}$ & $0,774^{\mathrm{ab}}$ & $0,534^{\mathrm{b}}$ & 0,117 & 0,002 & 0,877 & 0,796 & 0,014 \\
\hline CTFDN (Kg/día) & $0,665^{\mathrm{a}}$ & $0,604^{\mathrm{ab}}$ & $0,514^{\mathrm{b}}$ & $0,304^{\mathrm{c}}$ & 0,052 & $<, 001$ & 0,171 & 0,697 & 0,001 \\
\hline CTFDA (Kg/día) & $0,548^{\mathrm{a}}$ & $0,480^{\mathrm{ab}}$ & $0,392^{\mathrm{b}}$ & $0,274^{\mathrm{c}}$ & 0,042 & 0,001 & 0,572 & 0,960 & 0,002 \\
\hline CTPB (Kg/día) & $0,165^{\mathrm{a}}$ & $0,158^{\mathrm{ab}}$ & $0,142^{\mathrm{b}}$ & $0,106^{\mathrm{c}}$ & 0,014 & 0,006 & 0,312 & 0,862 & 0,033 \\
\hline F/C & ----- & $87 / 13^{\mathrm{a}}$ & $71 / 29^{b}$ & $49 / 51^{c}$ & 2,074 & $<, 000$ & 0,904 & 0,875 & $<, 000$ \\
\hline DTAIVMS (\%) & $70,76^{\mathrm{a}}$ & $72,60^{\mathrm{a}}$ & $78,82^{\mathrm{ab}}$ & $82,96^{\mathrm{b}}$ & 2,253 & $<, 000$ & 0,616 & 0,523 & 0,004 \\
\hline
\end{tabular}

$\mathrm{A}_{1}: 100 \%$ hay de alfalfa ad libitum.

$\mathrm{A}_{2}: 0.5 \% \mathrm{LW} /$ day of ground corn and alfalfa hay ad libitum in the diet.

$\mathrm{A}_{3}: 1 \% \mathrm{LW} /$ day of ground corn and alfalfa hay ad libitum in the diet.

$\mathrm{A}_{4}: 1.5 \% \mathrm{LW} /$ day of ground corn and alfalfa hay ad libitum in the diet.

CMST: Total dry matter intake $(\mathrm{Kg})$.

DTAIVMS: Total apparent digestibility in vivo of dry matter $(\%)$.

CMSTD: Total digestible dry matter intake (Kg/day).

CMSF: Dry matter intake of forage (Kg/day).

CTFDN: Total FDN intake ( $\mathrm{Kg} /$ day).

CTFDA: Total FDA intake ( $\mathrm{Kg} /$ day).

CTPB: Total PB intake (Kg/day).

$\mathrm{F} / \mathrm{C}$ : ratio forage/concentrate $(\%)$.

EE: Standard error.

L: Probability value associated with a linear effect level of supplementation with corn in contrast orthogonal polynomial.

Q: Probability value associated with a quadratic effect level of supplementation with corn in contrast orthogonal polynomial

C: Probability value associated with a cubic effect level of supplementation with corn in contrast orthogonal polynomial.

$P$ valor: Equal letters indicate no significant differences for the 5\% probability. 
Table 3: CMST, CMSF, CTFDN, CTFDA, CTPB, DTAIVMS, F / C of the experiment II

\begin{tabular}{|c|c|c|c|c|c|c|c|c|c|}
\hline \multirow{2}{*}{ Ítem } & \multicolumn{4}{|c|}{ Diet } & \multirow{2}{*}{$\mathbf{E E}$} & \multicolumn{3}{|c|}{ Contrast } & \multirow[t]{2}{*}{ P-value } \\
\hline & $\mathbf{R}_{1}$ & $\mathbf{R}_{\mathbf{2}}$ & $\mathbf{R}_{\mathbf{3}}$ & $\mathbf{R}_{4}$ & & $\mathbf{L}$ & $\mathbf{Q}$ & $\mathbf{C}$ & \\
\hline CMST (Kg/day) & $0,713^{\mathrm{a}}$ & $0,803^{\mathrm{ab}}$ & $0,944^{b}$ & $1,223^{\mathrm{c}}$ & 0,083 & 0,000 & 0,218 & 0,790 & 0,003 \\
\hline CMSF (Kg/day) & $0,713^{\mathrm{a}}$ & $0,560^{\mathrm{a}}$ & $0,505^{\mathrm{a}}$ & $0,596^{\mathrm{a}}$ & 0,094 & 0,315 & 0,186 & 0,466 & 0,401 \\
\hline CTFDN (Kg/day) & $0,527^{\mathrm{a}}$ & $0,448^{\mathrm{a}}$ & $0,449^{\mathrm{a}}$ & $0,527^{\mathrm{a}}$ & 0,068 & 0,998 & 0,261 & 0,993 & 0,704 \\
\hline CTFDA (Kg/day) & $0,313^{\mathrm{a}}$ & $0,256^{\mathrm{a}}$ & $0,202^{\mathrm{a}}$ & $0,287^{\mathrm{a}}$ & 0,074 & 0,886 & 0,325 & 0,898 & 0,866 \\
\hline CTPB (Kg/day) & $0,041^{\mathrm{a}}$ & $0,052^{\mathrm{b}}$ & $0,059^{c}$ & $0,080^{\mathrm{d}}$ & 0,006 & 0,000 & 0,237 & 0,546 & 0,003 \\
\hline F/C & ---- & $69 / 31^{a}$ & $54 / 46^{\mathrm{b}}$ & $46 / 54^{\mathrm{c}}$ & 0,052 & 0,000 & 0,060 & 0,697 & 0,001 \\
\hline DTAIVMS (\%) & $35,55^{\mathrm{a}}$ & $40,00^{\mathrm{a}}$ & $57,86^{\mathrm{b}}$ & $69,43^{\mathrm{c}}$ & 4,578 & 0,000 & 0,363 & 0,303 & 0,002 \\
\hline
\end{tabular}

$\mathrm{R}_{1}: 100 \%$ hay de $\mathrm{CN}$ ad libitum.

$\mathrm{R}_{2}: 0.5 \% \mathrm{LW} /$ day of ground corn and $\mathrm{CN}$ hay ad libitum in the diet.

$\mathrm{R}_{3}: 1 \% \mathrm{LW} /$ day of ground corn and $\mathrm{CN}$ hay ad libitum in the diet.

$\mathrm{R}_{4}: 1.5 \% \mathrm{LW} /$ day of ground corn and $\mathrm{CN}$ hay ad libitum in the diet.

CMST: Total dry matter intake $(\mathrm{Kg})$.

DTAIVMS: Total apparent digestibility in vivo of dry matter (\%).

CMSTD: Total digestible dry matter intake (Kg/day).

CMSF: Dry matter intake of forage (Kg/day).

CTFDN: Total FDN intake (Kg/day).

CTFDA: Total FDA intake (Kg/day).

CTPB: Total PB intake (Kg/day).

F/C: ratio forage/concentrate (\%).

EE: Standard error.

L: Probability value associated with a linear effect level of supplementation with corn in contrast orthogonal polynomial.

Q: Probability value associated with a quadratic effect level of supplementation with corn in contrast orthogonal polynomial

C: Probability value associated with a cubic effect level of supplementation with corn in contrast orthogonal polynomial.

$P$ valor: Equal letters indicate no significant differences for the 5\% probability.

Table 4: Variance analysis, relation between total dry matter intake and total PB intake

\begin{tabular}{lccccc}
\hline Item & Sum of squares & GI & Mean square & F-Ratio & P-Value \\
Model & 827151 & 1 & 827151 & 113,08 & 0,0000 \\
Residue & 102411 & 14 & 7315,04 & & \\
Total (Corr.) & 929562 & 15 & & & \\
\hline
\end{tabular}

Correlation coefficient $=0,943308$

R-cuadrad $=88,9829 \%$

Table 5: Variance analysis, relation between total dry matter intake and total and total apparent digestibility in vivo of dry matter

\begin{tabular}{lccccc}
\hline Item & Sum of squares & Gl & Mean square & F-Ratio & P-Value \\
Model & 331234 & 1 & 331234 & 7,75 & 0,0146 \\
Residue & 598328 & 14 & 42737,7 & & \\
Total (Corr.) & 929562 & 15 & & & \\
\hline
\end{tabular}

Correlation coefficient $=0,596936$

$\mathrm{R}$-cuadrad $=35,6333 \%$ 
Figure 1: Intake of CTMS, CMSF y CMSmz; experiment I. Substitute effect

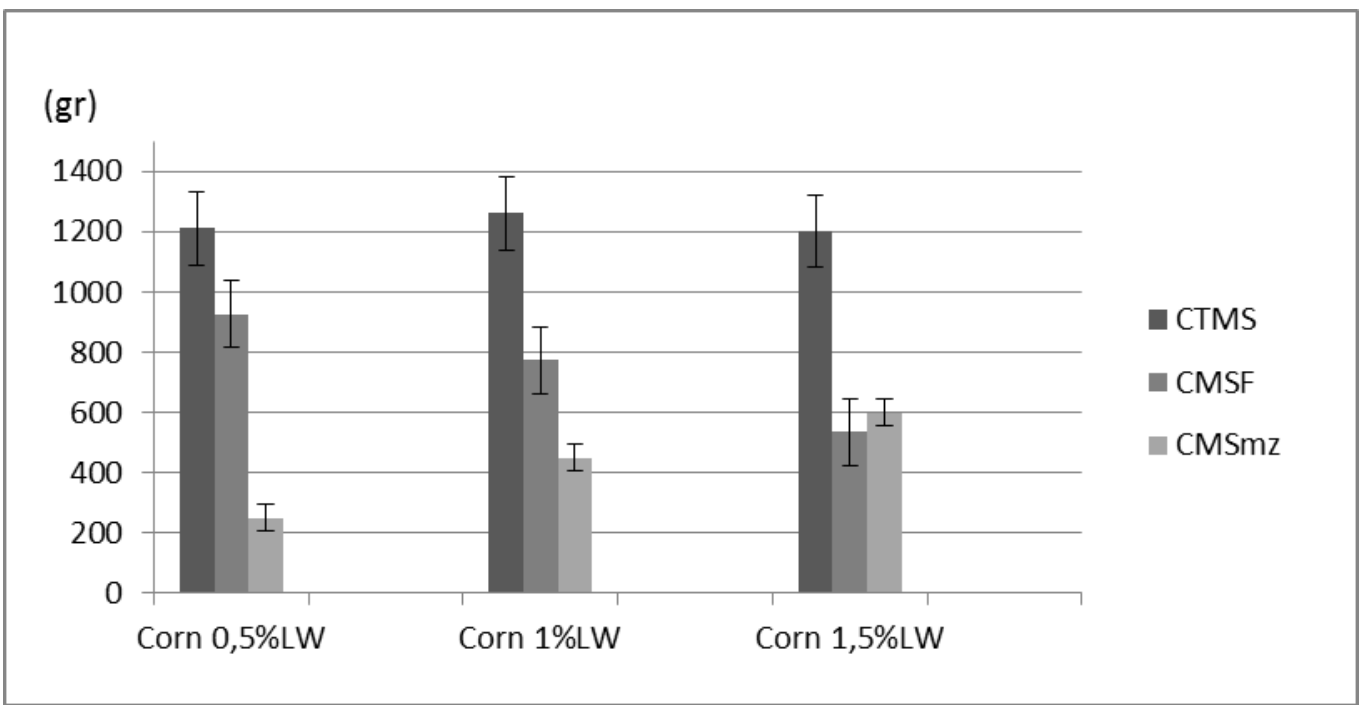

CTMS: Total dry matter intake (gr).

CMSF: Dry matter intake of forage (gr).

CMSmz: Dry matter intake of corn (gr).

Figure 2: Intake of CTMS, CMSF and CMSmz; experiment II. Substitute additive

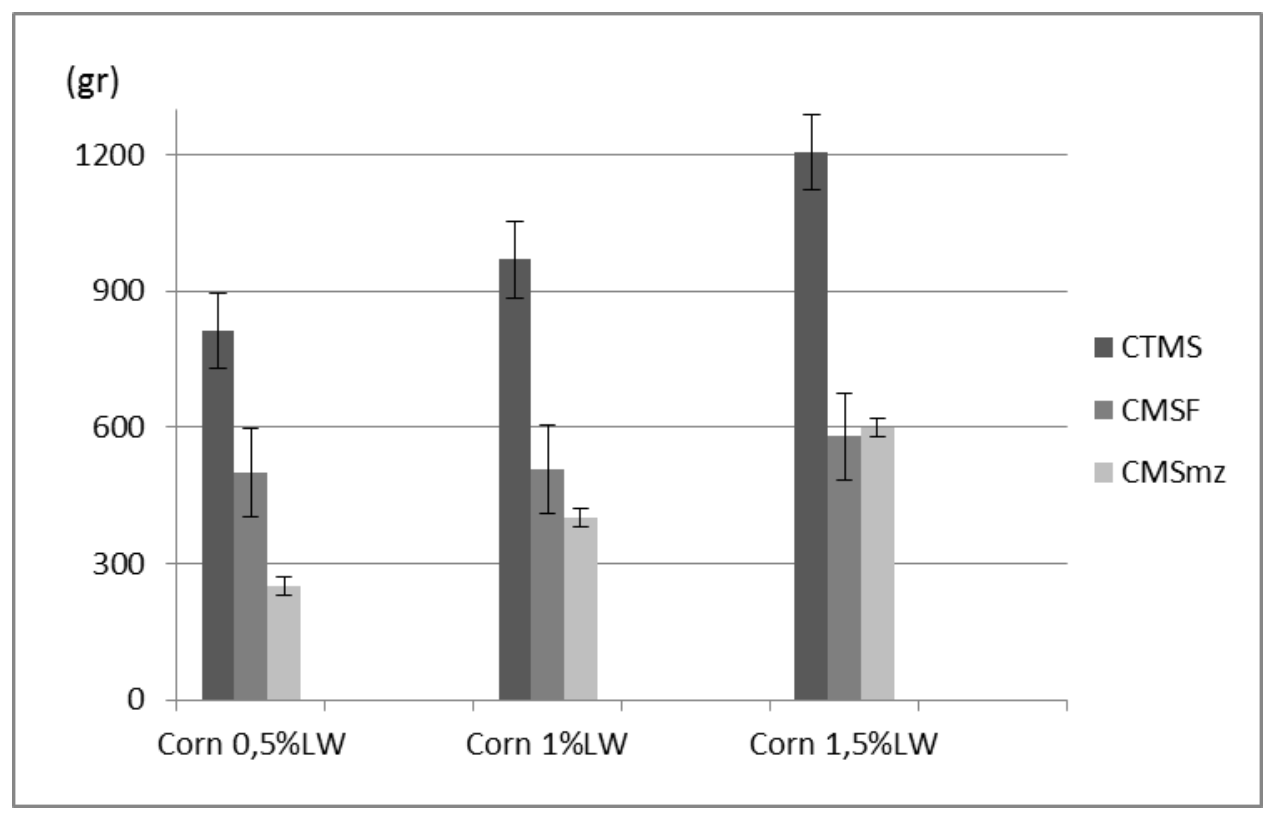

CTMS: Total dry matter intake (gr).

CMSF: Dry matter intake of forage (gr).

CMSmz: Dry matter intake of corn (gr). 
Figure 3: Simple regression between the total dry matter intake and total intake of PB

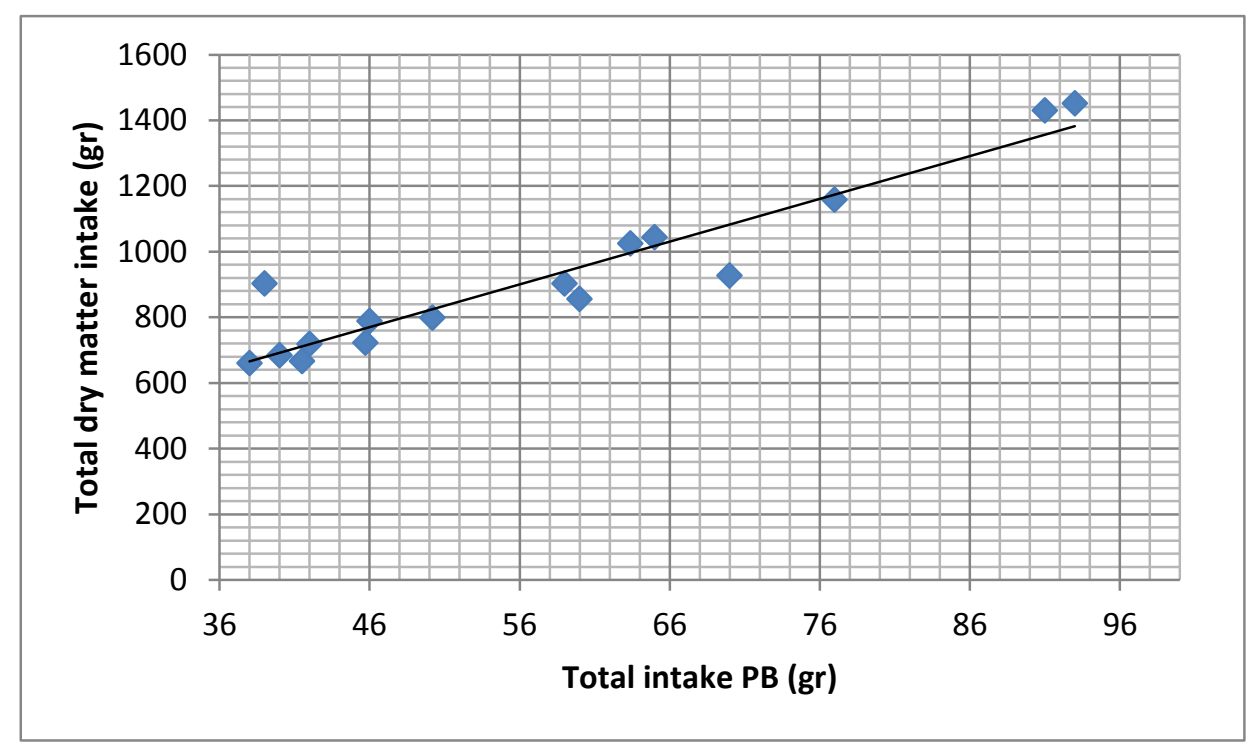

Figure 4: Simple regression between the total dry matter intake and total dry matter digestibility

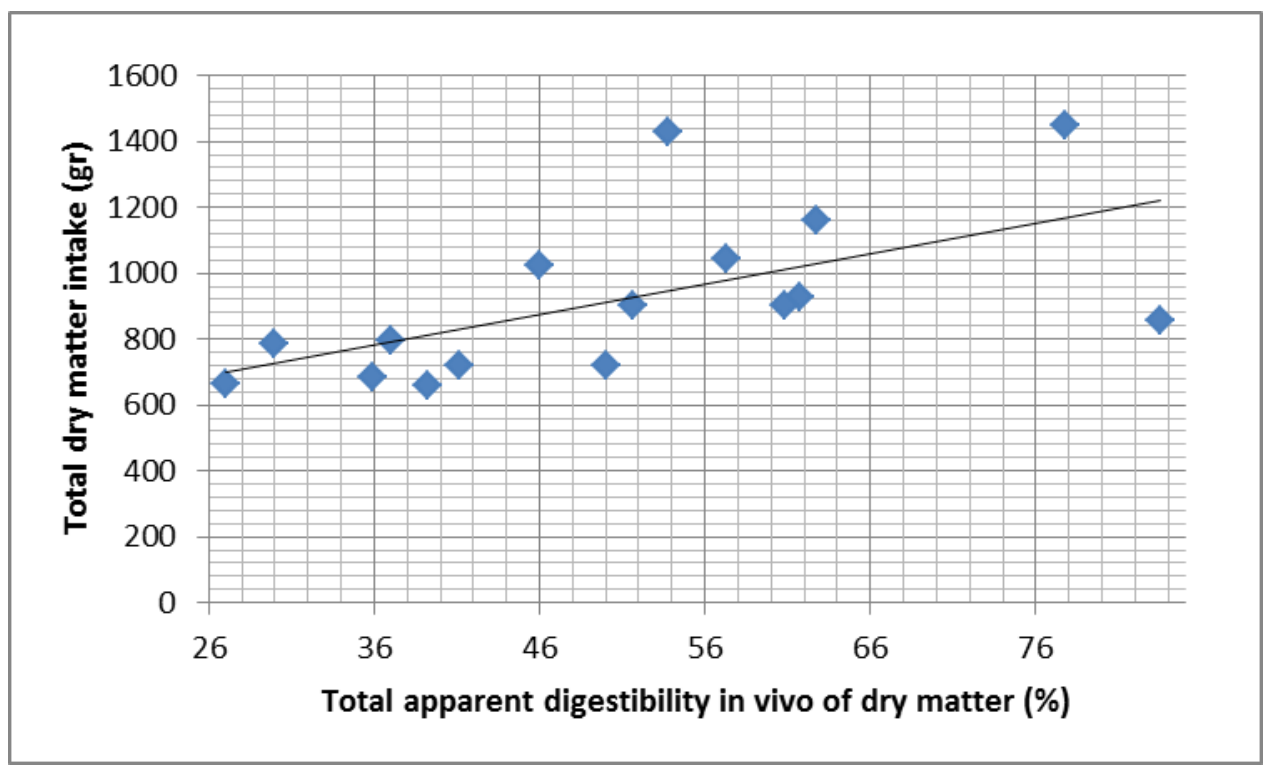

